„Bohemistyka” 2019, nr 2, ISSN 1642-9893

Tatiana ANIKINA

DOI: $10.14746 /$ bo. 2019.2 .3

Lidia GRIGORIEVA

St. Petersburg State University

\section{Features of the text field of the First Psalm of Psalter in Czech and Polish tradition}

Keywords: psalter, Psalm 1, Bible kralická, Czech ecumenist translation, Jan Kochanowski, Czesław Miłosz, Jakub Wujek

\section{Abstract}

This article is about comparing the transcriptions of Psalm 1 in Psalter into Czech and Polish. The Bible kralická, the Czech ecumenist translation, the translation of Fajman representing the Czech hymnological tradition and the transcriptions of psalms into Polish by Jakub Wujek, Jan Kochanowski and Czesław Miłosz are considered. The stylistic analysis suggests that the Hussite tradition is strong in Czech hymnology. The latter suggests utmost simplicity and accessibility of understanding of biblical texts. Polish tradition preserves the ambiguity of biblical word, and the associated ambiguity in interpretation of the nuances of biblical text. The arrangements of Kochanowski employ more complex metaphoricity and tend to clarify the text of the Psalm.

Psalter - the book of psalms or hymns is, probably, the most famous part of the Holy Scripture in Europe.

Regarding structure, all the psalms are composed according to the rules of Jewish poetry. The Psalter metric organization is based on parallelism (Вэндленд 2009, p. 39). Parallelism can be built on variations of one same thought, on a thought and its concretization, on two opposite thoughts or on two statements based on the principle of gradation. Another important feature of Hebrew poetry is its enhanced metaphorism (Вэндленд 2009, p. 82).

We settled on the first Psalm of the Psalter. The origin of Psalm 1 is not completely clear: whether it really was the first hymn of David, or, on the contrary, it was written later as an introduction to the Book of
Psalms (Пьянков 1874). In any case, Psalm 1 possesses an increased semantic load. So, the appeal to its text is of apparent interest.

According to theologians, the first psalm is dedicated to the beatus state of the righteous man leading a moral life in contrast to the state leading to death of the wicked (Разумовский 2018).

Tento žalm moudrosti nás vede, abychom zkoumali především Hospodinovy „rady” a přemýšleli o tom, zda náš život je v souladu s nimi (Fajmon 2018).

Psalm 1, as any biblical text is difficult to understand because of its enhanced metaphorism and allows for various nuances in interpretation. The role of metaphors in two national traditions of Psalter transcriptions in the world of Slavia Latina: the Czech and the Polish - have been addressed.

\section{Psalm texts}

1. According to G. Razumovsky the outset of the psalm is interpreted as follows:

[...] blessed is he who is pure in heart, who has pure thoughts and if he goes astray from the righteous path, he does not persist in his delusions, he does not adjoin persecutors of faith and undoes of morality (Разумовский 2018).

On the one hand, Bible kralická was created by the Czech Brothers in accordance with the Hussite doctrine of accessibility and clarity of biblical texts to ordinary people. On the other hand, it should be as close as possible to the original ancient texts. In addition, the translation was composed in the 16 th century and it could not be free from the rhetorical norms of the era. In this regard, in the first verse of the Psalm the metaphor-gradation is preserved. This is typical in ancient Hebrew poetry (Аверинцев 1983, p. 271-302) with use of singleterm metaphors-symbols: rada bezbožných, cesta hřišnikio, stolice posměvaču, rada ztych.

Blahoslavený ten muž, kterýž nechodí po radě bezbožných, a na cestě hříšníků nestojí, a na stolici posměvačů nesedá (Bible kralická 2018). 
The same principle can be found in other West Slavonic translations, in particular, in Polish translations of the 17th century:

Błogosławiony mąż, który nie chodził w radzie niezbożnych i na drodze grzesznych nie stał, i na stolicy zaraźliwości nie siedział (Pismo Święte... 1972).

$$
\begin{aligned}
& \text { Szczęśliwy, który nie był miedzy złymi w radzie } \\
& \text { Ani stóp swoich torem grzesznych ludzi kładz } \\
& \text { Ani siadł na stolicy, gdzie tacy siadają, } \\
& \text { Co się z nauki zdrowej radzi naśmiewają } \\
& \text { (Kochanowski 1997) }
\end{aligned}
$$

Polish authors retain complex metaphor-gradation by resourcing to metaphor-symbols: tor grzesznych, rada bezbożnych, droga grzeszników, gromada naśmiewców.

In the modern Czech ecumenical translation of 1979 a simplification of the metaphor can be observed. This corresponds to the general Czech confessional concept aimed at accessibility and the uniqueness of the biblical texts associated with it:

Blaze muži, který se neřídí radami svévolníků, který nestojí na cestě hř́ǐných, který nesedává s posměvači (Žalmy. Český... 2018).

In the modern Fajmon translation the metaphor is getting even more simple:

Št’astný je ten, kdo se neřídil radou zlovolníků, a neusedl mezi chvastouny (Fajmon 2018).

Thus, it can be said that the Hussite traditions are striving for simplicity and accessibility of the Holy Scripture. These are still strong in the Czech Republic and designate in shaping the field of biblical texts.

Meanwhile in Polish translation of 1979 by Czesław Miłosz, the metaphor-gradation is preserved:

Szczęśliwy, kto nie chodził za radą bezbożnych

i na drodze grzeszników nie postał,

i w gromadzie naśmiewców nie siedział

$$
\text { (Miłosz 1981) }
$$

While Czech tests clearly show a general tendency towards a simplified understanding of the Bible, each Polish author relies on the biblical text and creates a metaphor in accordance with the rhetorical norms of the literature of his time. A more vivid metaphor of Kochanowski and the extremely simple metaphor of Miłosz can be observed. Kochanowski's metaphors can be attributed to the monomials metaphors. Although, as if "clarified", thanks to their development: tor grzesznych ludzi; stolica, gdzie tacy siadaja, co się z nauki zdrowej radzi naśmiewaja, which conceptually bring together the transcription of Psalter of Kochanowski with Bible kralická. Miłosz builds a metaphor based on a strict repetition of past tense verbs: nie chodzit, nie postat, nie siedziat. The monotony of repetition is enhanced by the forms of droga grzeszników; gromada grzeszników. Such strict adherence to biblical hymnographic principles allows the author to preserve the ambiguity of the biblical text and, consequently, the variability of its interpretations. This among other things corresponds to the principles of modern poetry, which is influenced by postmodernist traditions with their primacy of the reader and infinite plurality of interpretations of the texts.

2. The next line of the psalm contains a hidden quotation from the Book of Nun, which says that a person can succeed in all his endeavors if he is firm in his convictions and follows the Book of the Law of God strictly while constantly thinking about it (1:7-8). This is the piety of the believer and the state of bliss associated with him (Разумовский 2018).

Polish translation of Wujek accurately conveys the thought of the psalm:

Ale w zakonie PANSKIM wola jego, a w zakonie jego będzie rozmyślał we dnie i w nocy (Pismo Święte... 1972).

Kochanowski unfolds a detailed metaphorical picture once again.

$$
\begin{aligned}
& \text { Ale to jego umysł, to jego staranie, } \\
& \text { Aby na wszytkim pełnił Pańskie przykazanie; } \\
& \text { Dzień li po niebie wiedzie, noc li swoje konie }
\end{aligned}
$$


The author impersonate the day and the night, conveying the images that are peculiar to the mythological consciousness. This can be attributed to psychological parallelism, which increases the impact of the text of psalm on the reader. Impersonation is created by the allegorical use of the verb wieść, which characterizes actions of a man as well as the image of the night on a horse. The latter.

Showing the steadiness of action - remain in prayer, Kochanowski uses parallel structures: to jego umyst, to jego staranie, dzień li, noc li.

The translation of Miłosz is closer to the text of psalm. Nevertheless, the steadiness of action in it is also preserved but transmitted in a different philosophical way, which corresponds to the attitudes of the poetics of Miłosz. The concept of "day and night" has become the subject of theological treatises more than once (Каллист 2004, Лопухин 1904-1912) The general opinion is that the expression day and night should be understood in the meaning of constantly, continuously, forever, that is infinitely (Баринов 2018). Thus, Miłosz also speaks of the continuous prayerful state of the pious resorting to the metaphorical phrase ,day and night”.

$$
\begin{aligned}
& \text { Ale w prawie Pańskim ma upodobanie } \\
& \text { i naukę Pańską bada w dzień i w nocy. }
\end{aligned}
$$$$
\text { (Miłosz 1981) }
$$

3. The third and the fourth lines of Psalm 1 continue the comparison of the pious man with the ungodly. The interpretation on Psalm 1, as well as the translation of the Psalm is quite simple, raditionaly for Czech: the tree is a symbol of the righteous, and the chaff - a symbol of the unrighteous (Fajmon 2018)

3. Nebo bude jako strom štípený při tekutých vodách, kterýž ovoce své vydává časem svým, jehožto list nevadne, a cožkoli činiti bude, št’astně [mu] se povede.

4. Ne takt' [budou] bezbožní, ale jako plevy, kteréž rozmítá vítr (Bible kralická 2018).

Czech ecumenical translation replaces the more rare word štipený with the modern zasazený:
3. Je jako strom zasazený u tekoucí vody, který dává své ovoce v pravý čas, jemuž listí neuvadá. Vše, co podnikne, se zdaří.

4. Se svévolníky je tomu jinak: jsou jak plevy hnané větrem (Žalmy. Český... 2018)

Fajman's translation further simplifies the text by replacing pravý čas with čas sklizně:

3. Je jako strom zasazený u tekoucích vod,který nese ovoce v čas sklizně a jemuž listí neuvadá - vším, co dělá, působí zdar.

4. Ne tak zlovolníci - ti jsou jako plevy, kterými zmítá vítr (Fajman 2018).

In this passage the pious is compared to not a simple tree, but to a tree planted near the water that is not poised to drought. A tree that will bear fruit in due time. The image of water in the Bible is ambivalent. Water can mean life or death, blessing and grief, order or chaos. In this case water is the source of life, blessing and order. A tree according to the testimony of the Dictionary of biblical images has a very special status in the Bible due to the fact that in Palestine a tree is a rarity. In addition, a tree is a symbol of vitality. Therefore, a tree that survives even during a drought, thanks to its strong roots, is an excellent illustration of the constancy of a believer in any circumstances, good or bad (Райкен, Уилхойт, Лонгман 2018). Based on the simplified Czech translation it is difficult to say whether it is a complex of religious concepts related to water and a tree that arise in the mind of a believer, or otherwise it is the image of a fruit tree yielding crop that is simply associated with this passage.

The transcription of the psalm of Wujek (Pismo Świete... 1972) follows the text biblically:

3. I będzie jako drzewo, które wsadzone jest nad ściekaniem wód, które swój owoc da czasu swego, a liście jego nie opadnie: i wszytko, cokolwiek czynić będzie, poszczęści się (Pismo Święte... 1972).

Kochanowski creates a detailed comparison in which wildlife becomes central - the tree. The object of comparison is a pious man and the psalm is dedicated to his characteristics. An object of such matter and the centre of comparison bring it closer to the psychological paral- 
lelism that is peculiar to folklore (Веселовский 1913). The comparison is supported by a wide context that describes the centre of comparison in detail. The comparison is introduced by the podobien bedzie construction. The author adds an explanation to the biblical text: a time when a tree can wither.

$$
\begin{aligned}
& \text { 3. Taki podobien będzie drzewu porzecznemu, } \\
& \text { Które przynosi co rok owoc panu swemu } \\
& \text { Liścia nigdy nie tracąc, choć zła chwila przydzie } \\
& \text { Temu wszystko, co pocznie, na dobre wynidzie. }
\end{aligned}
$$$$
\text { (Kochanowski 1997) }
$$

Czesław Miłosz strictly follows the biblical text and does not colour the image. The comparison introduces a construction będzie jak. Nevertheless, both the centre of comparison and its object are the same for Miłosz and for Kochanowski's. Although the context that supports the comparison is simpler. In this case, it is also possible to talk about psychological parallelism.

\footnotetext{
3. będzie jak drzewo zasadzone u strumieni wód,

które wydaje owoc, kiedy jest jego czas,

i którego liść nie usycha.

A cokolwiek zacznie, powiedzie się

(Miłosz 1981)
}

And since they did not see fit to acknowledge God, God gave them up to a debased mind to do what ought not to be done. They were filled with all manner of unrighteousness, evil, covetousness, malice. They are full of envy, murder, strife, deceit, maliciousness. They are gossips, slanderers, haters of God, insolent, haughty, boastful, inventors of evil, disobedient to parents, foolish, faithless, heartless, ruthless (Romans 1:28-31).

Since the basic law of Hebrew poetry was parallelism (Десницкий 2007) after describing the pious in the psalm the text then refers to the wicked, which are described in the fourth line of the psalm. The wicked do not know God and refuse to seek and know Him. Their deeds are deprived of God's help and, therefore, they are destroyed and do not bear fruit and have no beneficial consequences. Being god- less they live in sin and indulge in all vices and all shameful passions (Romans 1: 24-32). Being evil and foolish themselves they persecute believers ( $\mathrm{J}$ 16:23)

4. Nie tak niezbożni, nie tak, ale jako proch, który rozmiata wiatr z wierzchu ziemie (Pismo Święte... 2018).

In the translation of Wujek the tares are transmitted as dust thrown up by the wind.

Describing the wicked Kochanowski creates a comparison that is introduced by the lexical item równi. The object of comparison are the wicked. The centre of comparison are the tares carried by the wind wherever they like. In both Testaments concrete actions related to the harvest reap express the images of God's judgment on evil (Райкен, Уилхойт, Лонгман 2018). Like in the previous line of the psalm the author applies the techniques of psychological parallelism and repeats the techniques of Hebrew poetry. Kochanowski expands the image by creating a figurative context and describes the tears in detail: które sie walaja przy ziemi, and wiatry, gdzie jedno chca, wszędzie wtadna je$m u$. This detailed picture clarifies the image and enhances the effect of the text on the reader:

$$
\begin{aligned}
& \text { 4. Ale źli, którzy Boga i wstydu nie znają, } \\
& \text { Tego szczęścia, tej nigdy zapłaty nie mają: } \\
& \text { Równi plewom, które się walają przy ziemi, } \\
& \text { A wiatry, gdzie jedno chcą, wszędzie władną jemu. }
\end{aligned}
$$$$
\text { (Kochanowski 1997) }
$$

Miłosz also creates a comparison introduced by the construction nie tak, nie tak, ale jak. The object and the centre of comparison is the same as that of Kochanowski. In the parable of wheat and tares the growth of grains with poisonous weeds, known as tares, altogether symbolizes the conditions in which Christians must live in the same world with unbelievers up to the Doomsday (Mt 13:24-30, 36-42) (Райкен, Уилхойт, Лонгман 2018). It should be noted that the image of Miłosz is much more syncretistic. He follows the biblical original more strictly. 
4. Nie tak bezbożni, nie tak.

Ale są jak plewy, które wiatr wymiata.

(Miłosz 1981)

In accordance with the author's attitudes and the poetics adopted at that time both images convey one of the central thoughts of the psalm: The story of salvation is like a slow advancement to the climax of the harvest. God and His workers plant a field in the world. God cares for growing crops which inevitably approach the time of harvest. When the crop ripens God gathers it and separates the fruits and grains from impurities and chaff (Райкен, Уилхойт, Лонгман 2018).

4. The Psalm further states that the wicked will not stand in judgment with the righteous (Mt 25:32). They will be condemned together with sinners. After the resurrection the righteous and the pious will follow into the kingdom of God, into Eternal Life. All authors strive to follow the text of the original as precisely as possible:

A protož neostojí bezbožní na soudu, ani hř̌́šníci v shromáždění spravedlivých (Bible kralická 2018).

Na soudu svévolní neobstojí, ani hříšní v shromáždění spravedlivých (Žalm. Český... 2018).

Proto zlovolníci neobstojí na soudu, ani hříšníci ve shromáždění spravedlivých (Fajmon 2018).

Przetoż nie powstaną niezbożnicy na sądzie ani grzesznicy w zebraniu sprawiedliwych (Pismo Święte... 1972).

Dla czego przed sądem być muszą pohańbien

Ani w liczbie z dobrymi będą policzeni;

$$
\text { (Kochanowski 1997) }
$$

Przeto nie ostoją się bezbożni na sądzie

ani grzesznicy w zgromadzeniu sprawiedliwych.

\section{(Miłosz 1981)}

5. The final line of the psalm means that the Omniscient and Righteous Judge knows everything (Разумовский 2018). In the Czech version:
Nebot’ zná Hospodin cestu spravedlivých, ale cesta bezbožných zahyne (Bible kralická 2018).

Hospodin zná cestu spravedlivých, ale cesta svévolníků vede do záhuby (Žalm Český... 2018)

Vždyt' Hospodin zná cestu spravedlivých, ale cesta zlovolníků zanikne (Fajmon 2018)

Abowiem zna PAN droge sprawiedliwych, a droga niepobożnych zginie (Pismo Święte... 1972).

$$
\begin{aligned}
& \text { Albowiem poznaje Pan drogę sprawiedliwych, } \\
& \text { a droga bezbożnych zaginie. Sela. }
\end{aligned}
$$

(Miłosz 1981)

Following the original the authors use the monomial image-symbol of the path of the righteous and the path of the wicked.

The path is usually understood not as a road that we walk but all our deeds, thoughts and intentions and, therefore, the final words of the psalm: the path of the wicked will perish, which means that the works, plans and schemes of the wicked and with all this themselves will perish (Разумовский 2018).

Kochanowski in accordance with his rhetorical attitudes explains the text of the psalm in a metaphorical form again:

Pan bowiem sprawiedliwych na wszelki czas broni,
A przewrotne, złe ludzi cicha pomsta goni.

(Kochanowski 1997)

\section{Conclusion}

Tento žalm neslouží $\mathrm{k}$ tomu, abychom na základě něj soudili jiné - zda jsou druzí těmi spravedlivými, nebo těmi zlovolníky - ale abychom posoudili své vlastní jednání, zda my sami neprožíváme tento den tak nějak „,bez Boha”. Tento žalm moudrosti nás vede, abychom zkoumali především Hospodinovy „rady” a přemýšleli o tom, zda náš život je v souladu s nimi. Mluví se zde o tom, co je možná ještě skryté a není zcela zřejmé - že Hospodin zná cestu a že jiné cesty zaniknou, nedojdou naplnění a cíle. Budeme mu věřit, že Jeho cesta má smysl a cíl? Pokud ano, možná na Jeho cestě zakusíme zázrak proměny života neplodné plevy v život stromu, který nepostrádá vláhu a nese ovoce (Fajmon 2018). 
So, the stylistic analysis of the texts suggests that the Hussite tradition is strong in Czech hymnology suggesting the utmost simplicity and accessibility of the understanding of biblical texts. Polish tradition preserves the ambiguity of the biblical word and the associated ambiguity in the interpretation of the nuances of the biblical text. The arrangements of Kochanowski, which possess a more complex metaphoricity, tend to clarify the text of the Psalm.

\section{Bibliography}

Bible kralická. Online: https://cs.wikisource.org/wiki/Bible_kralická/Žalmy [cit. 08.04.2018].

Biblia w przekladzie ks. Jakuba Wujka. Strona Biblijna, 2018. Online: http://biblijna. pl/teksty/przeklad pol wujek.php [dostęp: 19.11.2018].

B o h a t c o vá M., 1959 Bible kralická: její vznik a význam. In: V. Fialová, Kralice. Brno, s. 49-61.

F aj m on B., 2018, Rozhovor nad bibli. Online: http://www.rozhovor.cz/zalmy/ zalm001.php [cit. 08.04.2018].

K o c h a n o w s k i J., 1997, Psatterz Dawidów, Kraków.

K o z i a r a S., 2003, Biblia Wujka w języku i kulturze polskiej. „Konspekt”, nr 14-15. Online: http://web.archive.org/web/20090610032103/http://biblijna.strona. pl/teksty/biblia_wujka_w_jezyku_i_kulturze.htm [dostęp: 08.04.2018].

Miło s z Cz., 1981, Księgi biblijne: przeklady z języka greckiego i hebrajskiego. Paris.

Pismo Święte Starego i Nowego Testamentu, 1962, przekład Jakuba Wujka, Wydawnictwo Apostolstwa Modlitwy.

Žalmy. Český ekumenický překlad, 2018. Online: http://www.biblenet.cz/b/Ps/1 [cit. 08.04.2018].

А в е р и н ц е в С.С., 1983, Древнееврейская литература, [в:] История всемирной литературы. Москва, т. 1, с. 271-302.

А ф а н а с ь е в А.Н., 1982, Древо жизни. Москва.

Б а р и н о в Н. протоиерей, 2018, Опровержение учения о всеобщем спасении на основании Священного Писания, трудов святых отиов и деяний Вселенских Соборов. К вопросу о вечных муках - Азбука веры. Online: https://azbyka.ru/otechnik/bogoslovie/oproverzhenie-uchenija-o-vseobshhem-spasenii/\#0_4 [cit. 05.05.2018].
В е с е л о в с к и й А.Н., 1913, Психологический параллелизм и его формы в отражениях поэтического стиля, [в:] Собраные Сочитание, т. І. Санкт-Петербург.

В э н д л е н д Э.Р., 2010, Гармония и алгебра Псалтири: литературный и лингвистический анализ библейских псалмов. Москва.

Д е с н и ц к и й А., 2007, Поэтика библейского параллелизма. Москва.

К а л л и с т (Уэр), епископ Диоклийский, 2004, Внутреннее царство. Киев.

Ло пу х ин А.П., 1904-1912, Толковая Библия в 12-ти томах. Санкт-Петербург.

П ин с к и Р.,2008, Жизнь Давида. Москва.

П ь я н к о в П., 1874, Толкования на псалмы. Вятка.

Р а з умо в ский Г., 2018, Толкование священной книги псалмов. Online: https:azbyka.ru/otechnik/Grigorij_Razumovskij/objasnenie-svjashennoj-knigi-psalmov/1 [cit. 05.05.2018].

Р ай кен Л., У и лх ойт Д., Лонгман Т., 2018, Словарь библейских образов. Online: https://azbyka.ru/otechnik/Spravochniki/slovar-biblejskih-obrazov/86 [cit. 08.04.2018] 